\title{
EDITORIAL: OCCUPATION
}

'Vae victis!' ('Woe to the vanquished!'). This exclamation by the Gaulish chieftain Brennus, dictating his terms after defeating ancient Rome, ${ }^{1}$ illustrates a historical reality: defeat on the battlefield has, over the centuries, entailed a series of misfortunes for the conquered peoples. Murder, rape, slavery, and plunder: conquest gave the victors absolute rights over people and their property, and it often meant the outright annexation of captured territories. 'To act as if one owns the place' is still a current expression that reflects the arbitrary actions of the conqueror - the principle that 'might makes right'.

Since the nineteenth century, the development of international humanitarian law has put an end to this seemingly inevitable chain of events by gradually expanding the protection of people who fall into enemy hands and by setting greater limits on the conduct of hostilities. The international system has also evolved, banning the use of force in relations between states, forced annexation, ${ }^{2}$ and colonization. ${ }^{3}$ Humanitarian law has developed in parallel and applies to armed conflict, regardless of its cause and legality.

At first glance, occupation seems to be well covered by treaty and customary law, to the extent that occupation law generally features among the traditional aspects of humanitarian law. During the American Civil War, a series of instructions for an occupying army became part of the rules of conduct of the Union forces, named after the legal scholar Francis Lieber. ${ }^{4}$ In international law, Section III of the Regulations concerning the Laws and Customs of War on Land, annexed to the Hague Conventions of 1899 and 1907, is entitled 'Military Authority over the Territory of the Hostile State'. Additional constraints on the occupier's conduct were introduced in the Geneva Conventions of 12 August 1949 and Additional Protocol I of 8 June 1977, so that the powers of occupiers are now governed by these instruments, most of which derive from customary international law.

The notion that the occupier's conduct towards the population of an occupied territory must be regulated underpins the current rules of humanitarian law governing occupation. Another pillar of this body of law is the duty to preserve the institutions of the occupied state. Occupation is not annexation; it is viewed as a temporary situation, and the Occupying Power does not acquire sovereignty over the territory concerned. Not only does the law endeavour to prevent the occupier from wrongfully exploiting the resources of the conquered territory; it also requires the occupier to provide for the basic needs of the population and to 'restore, and ensure, as far as possible, public order and safety, while respecting, unless absolutely 
prevented, the laws in force in the country'. ${ }^{5}$ The measures taken by the occupier must therefore preserve the status quo ante (this is known as the conservationist principle).

On closer inspection, however, occupation law leaves several questions without clear answers. Furthermore, in recent years, some states have proposed to reinterpret, or have even called into question, the traditional principles of occupation law. The occupation of Iraq in 2003-2004 provoked intense debate about the responsibilities of Occupying Powers and about occupation law in general. Some territories are still occupied today or are disputed by states. Generally, however, Occupying Powers tend to repudiate their status as occupiers under humanitarian law and deny the de jure applicability of occupation law to their actions in enemy territory.

Occupation remains a reality, and there is nothing to suggest that new situations of occupation will not arise in the future-for instance, as part of multinational operations. Situations of occupation remain dangerous geopolitical fault lines, which radicalize opinions and sow the seeds of future conflicts. Germany's annexation in 1871 of the French regions of Alsace and Lorraine set a precedent whose consequences for international stability reverberated until 1945 . The recurring tensions between Israel, Syria, Lebanon, and Iran are still largely linked to the fate of the Palestinian people and territory and have the potential to destabilize international relations well beyond the region.

Territorial disputes and situations of occupation lead to problems of humanitarian concern affecting occupied or exiled peoples. The inhabitants of occupied or contested territories may therefore be direct victims of hostilities or widespread violence, detained (jailed for breaking the law) or interned (held on security grounds) for long periods, or driven from their homes. In addition to having a direct military advantage resulting from effective control over enemy territory, the occupier may sometimes seek to change the demographic composition of the territory in order to create a new situation on the ground and quash any resistance. This might take place through a policy of forced displacement (sometimes called 'ethnic cleansing') or colonization of the territory. Millions of uprooted people languish in refugee camps in a permanent state of uncertainty, passing on their bitterness and desire for revenge to succeeding generations. Peoples' civil and political rights, as well as their economic and social rights, such as

1 Livy (Titus Livius), History of Rome from its Foundation (Ab Urbe Condita Libri), V.xlviii.9.

2 Charter of the United Nations, Art. 2, para. 4; UN General Assembly resolution 2625 of 24 October 1970, Declaration on Principles of International Law concerning Friendly Relations and Co-operation among States in accordance with the Charter of the United Nations, UN Doc. A/RES/25/2625.

3 See, for instance, the principle of equal rights and self-determination of peoples in Article 1, para. 2, of the UN Charter; Chapters XI, XII, and XIII of the UN Charter; General Assembly resolutions 1514 (XV) of 14 December 1960, Declaration on the Granting of Independence to Colonial Countries and Peoples, and UN General Assembly Resolution 2625, above note 2.

4 'Instructions for the Government of Armies of the United States in the Field', General Orders No. 100, US War Department, Government Printing Office, Washington DC, 24 April 1863 (the Lieber Code).

5 Regulations concerning the Laws and Customs of War on Land, annex to Convention (IV) respecting the Laws and Customs of War on Land, The Hague, 18 October 1907, Art. 43 (emphasis added). 
the right to education and the right to health care, are generally severely compromised by the imposition of a foreign military government, especially when it lasts for an extended period. Those opposing the occupation often resort to indiscriminate violence in order to gain recognition of their cause or to weaken their adversaries' resolve.

Humanitarian organizations working in occupied territories face numerous challenges and dilemmas. ${ }^{6}$ Although occupation is considered a conflict situation requiring the know-how of emergency relief agencies, when the situation persists and needs become chronic, humanitarian workers actually have to roll out postconflict development programmes. Moreover, for a humanitarian organization, meeting the basic needs of the population amounts to substituting itself for the Occupying Power and relieving it of its primary responsibility - a risky endeavour. The difficulty is how to be seen as neutral and impartial by the occupying army when the humanitarian needs lie mainly with the population of the occupied territory. Conversely, when the occupier controls access to the territory, working in co-ordination with it is unavoidable, but this may be interpreted as complicity with the occupier, or even as legitimizing the occupation.

As a humanitarian agency working in the field, the International Committee of the Red Cross (ICRC) operates, among other contexts, in situations of occupation and disputed territories to protect and assist victims. Given that it is directly confronted with the legal challenges posed by contemporary situations of occupation, the ICRC felt that it was necessary to check whether the rules of occupation should be strengthened, clarified, or developed. The organization therefore began consulting experts on occupation law and other forms of administration of foreign territory.

To coincide with the publication of the results of this project, ${ }^{7}$ the International Review of the Red Cross has decided to contribute to the discussion by devoting the present edition to the subject of occupation, and in particular to the grey areas and contentious issues arising from occupation law. The Review asked experts on matters related to occupation to offer their perspective, whether historical, military, or legal. The Review also wanted to hear from someone living in an occupied territory. Israel's occupation of the Palestinian territory and the Golan Heights is probably the defining occupation context of our time; the Review therefore interviewed Raja Shehadeh, lawyer, author, and co-founder of the Palestinian human rights organization $\mathrm{Al} \mathrm{Haq}$. Shehadeh offers a unique perspective on humanitarian law and human rights, both through practising law as part of the

6 See, e.g., Xavier Crombé, Humanitarian Action in Situations of Occupation, CRASH/Fondation Médecins Sans Frontières, January 2007, available at: http://www.msf-crash.org/en/publications/2009/06/03/241/ humanitarian-action-in-situations-of-occupation (last visited March 2012).

7 See Tristan Ferraro (ed.), Expert Meeting: Occupation and Other Forms of Administration of Foreign Territory, ICRC, Geneva, 2012, available at: http://www.icrc.org/eng/assets/files/publications/icrc-0024094.pdf (last visited March 2012). 
dialogue with Israel, and as an essayist committed to peace and peaceful co-existence between peoples.

The contributions brought together in this edition explore six key questions raised by contemporary situations of occupation, frame the issues, and set out to begin answering them.

\section{How and along what lines has occupation law developed?}

Occupation law has sometimes been called into question on the ground that it is no longer suited to contemporary situations. To help us understand the principles underpinning this body of law today, the first contributions to this edition trace the history of its development. Dating back to the Lieber Code, occupation law was originally the product of a state-centric view of international relations, concerned above all with protecting the rights of the sovereign whose territory was temporarily occupied by another power, but also with guaranteeing the latter's safety. Although from the same historical period, occupation law was not intended to apply to the colonial project of European states, because they denied the sovereignty of the subjugated peoples. World War I revealed another limitation of this nascent law: the inadequacy of the rules protecting civilians. The horrors endured by combatants in the trenches long obscured the suffering of people in occupied territories behind the front lines. The international community failed to learn the lessons of World War I and to improve the protection for civilians in enemy hands before the outbreak of the World War II. It was not until 1949 that their rights were spelled out in the Fourth Geneva Convention.

\section{When does the invasion phase end and the duties of occupiers and the rights of people living under occupation begin?}

'In the first weeks after the fall of Baghdad in April 2003, Iraqis would stop Americans on the street and ask who was in charge of the country. No one seemed to know. The Iraqi leadership had vanished, and the institutions of the state had collapsed'. 8 This quotation illustrates the confusion that exists with regard to determining the end of invasion and the beginning of occupation. The question of exactly when an occupation begins - and ends - is not regulated in detail by law. Yet it has very important practical and legal implications for both the population of the occupied territory and the military in charge of the intervention in enemy territory. For instance, at what point do they begin to be responsible to the population for providing services such as restoring the water and electricity supply and preventing looting? Must they re-establish and ensure public order and safety? Must they 
administer the public property of the occupied state from then on?9 Four specialists share their views on whether or not occupation law is applicable from the invasion phase. This key question of when occupation begins and ends is the subject of an article and of the legal debate section in the Review.

\section{Is the law always suited to prolonged occupation?}

According to the International Criminal Tribunal for the former Yugoslavia (ICTY): 'Occupation is defined as a transitional period following invasion and preceding the agreement on the cessation of the hostilities'. ${ }^{10}$ Since occupation is considered a temporary, short-term situation, it is difficult to reconcile the principles of this body of law with prolonged occupation. Does the length of the occupation challenge the conservationist principle by making it impossible or even harmful for the occupier to refrain from tampering with the socio-economic conditions of the territory? Doesn't the prolonged nature of the occupation also require greater emphasis on human rights, in particular on people's economic and social rights? The question of how important this time factor is for the applicability of occupation law is addressed by several contributors to this edition, particularly in the analysis of the decisions of the Israeli Supreme Court, the only court in the world to have admitted - and regularly handed down - verdicts on appeals from the population of an occupied territory.

\section{Is there any justification for changing the institutions and/or the laws of an occupied territory?}

Based on the precedents of the denazification of Germany and the reform of Japanese institutions after 1945, the occupation of Iraq was presented as an opportunity to reform the political system and democratize the country. Expressions such as 'nation-building', 'reconstruction', and 'transformative occupation' were used in this context. Consequently, are there 'good' occupations that justify an exception to the conservationist principle cited above? This question may arise when it comes to reforming an oppressive regime or rebuilding a devastated state. The legal validity of the concept of 'transformative occupation' is discussed in this edition.

9 For an illustration of this problem, see, e.g., Amnesty International, Iraq: Looting, Lawlessness and Humanitarian Consequences, MDE14/085/2003, New York, 10 April 2003 (a report published at the time of the invasion of Iraq, reminding the Occupying Powers of their obligations), and ICRC News Release 03/28 of 11 April 2003, which mentions the duties of Occupying Powers, available at: http://www.icrc.org/ eng/resources/documents/misc/5lhjp6.htm (last visited March 2012).

10 ICTY, The Prosecutor v. Mladen Naletilic and Vinko Martinovic, Case No. IT-98-34-T, Judgment (Trial Chamber), 31 March 2003, para. 214. 


\section{What is the role of the military in the occupation of a territory?}

How can an invasion force prepare for the occupation that will follow? What is the role of the military in a 'transformative occupation', in other words, a project of political, economic, and social reform? Managing and rebuilding an occupied territory are very different tasks from conquering it by force. In The Utility of Force, General Sir Rupert Smith writes:

It is necessary to understand that in many circumstances into which we now deploy, our forces as a military force will not be effective. The coalition forces in Iraq were a classic example of this situation: their effectiveness as a military force ended once the fighting between military forces was completed in May 2003. And though they then went on to score a series of victories in local skirmishes, they had greatly diminished - if any - effect as an occupation and reconstruction force, which had become their main mandate. ${ }^{11}$

The Review presents a US military perspective on the lessons to be learnt from the invasion and occupation of Iraq.

\section{What is the role of human rights in situations of occupation?}

Occupation, whether it occurs during or after an armed conflict, or without a declaration of war or even of hostilities, is governed by humanitarian law. What is the role of human rights law when it comes to maintaining order? What are the political, economic, and social rights of people in occupied territories when the situation persists? How can the application of those rights by the occupier be reconciled with the obligation to respect the laws and institutions in place? The decisions of the International Court of Justice ${ }^{12}$ recognize clearly that human rights law applies to situations covered by international humanitarian law. However, the exact scope of the occupier's responsibilities under human rights law needs to be clarified. A better understanding of the way in which these two complementary bodies of law apply means better protection for victims of conflicts.

Protecting people who fall into enemy hands is central to today's efforts to develop humanitarian law. Occupation law exemplifies this, as its purpose is to protect an entire population that has been placed in a highly vulnerable position. However,

11 Rupert Smith, The Utility of Force: The Art of War in the Modern World, Penguin Books, London, 2006, p. 10.

12 See International Court of Justice (ICJ), Advisory Opinion on the Legal Consequences of the Construction of a Wall in the Occupied Palestinian Territory, 9 July 2004, para. $102 \mathrm{ff}$; see also ICJ, Armed Activities on the Territory of the Congo (Democratic Republic of the Congo v. Uganda), Judgment, 19 December 2005, para. 178. 
people living under occupation and humanitarian organizations rarely succeed in obtaining compliance with the legal provisions. As the ICRC report points out:

In fact occupying States have repeatedly contested the applicability of occupation law to situations of effective foreign control over territory, which clearly shows their reluctance to be labelled as Occupying Powers and/or to see their actions constrained by this body of law. ${ }^{13}$

In a 1944 essay, Albert Camus wrote: 'Mal nommer un objet, c'est ajouter au malheur de ce monde' ('To misname things is to add to the misery of the world'). ${ }^{14}$ All too often, states resort to euphemisms and convoluted legal arguments to absolve themselves of their responsibilities. Through this edition, the Review seeks to contribute to a better understanding of occupation today and to the task of defining the rights and duties of the occupier.

Vincent Bernard Editor-in-Chief 